Saara Jantunen, MA, Department of Leadership and Military Pedagogy, National Defence University, Helsinki, Finland

Aki-Mauri Huhtinen, Professor, Department of Leadership and Military Pedagogy, National Defence University, Helsinki, Finland

\title{
THE HIDDEN GRAND NARRATIVE OF WESTERN MILITARY POLICY: A LINGUISTIC ANALYSIS OF AMERICAN STRATEGIC COMMUNICATION
}

\begin{abstract}
Strategic communication has replaced information warfare. As Art of War has been replaced by science, the representations of war and the role of the military have changed. Both war and military forces are now associated with binary roles: destruction vs. humanity, killing vs. liberating. The logic behind 'bombing for peace' is encoded in the Grand Military Narrative. This narrative is hidden in American (and NATO) strategies such as Effects Based Operations, which rely heavily on technology. As people aim to rationalize the world with technology, they fail to take into account the uncertainty it brings. In warfare, that uncertainty is verbalized as "friendly fire", "collateral damage" or simply as "accident". Success and failure are up to technology. Technology is no longer a tool, but an ideology and an actor that not only 'enables' the military to take action, but legitimizes it.

This article aims to contribute to military studies by analyzing, in the spirit of critical discourse analysis, American 'Grand Military Narrative' and the standard and trends of rhetoric it creates. The article focuses on pinpointing some of the linguistic choices and discourses that define the so-called 'techno-speak', the product of modern techno-ideology. These discourses result in representations of techno-centered binary values, which steer military strategy and foreign policy.
\end{abstract}

\section{Keywords}

Revolution in Military Affairs, Effects Based Operations, critical discourse analysis, military technology 


\section{Introduction}

On August 23, 2010, Reuters reported that missiles fired from a U.S. drone killed 13 militants and 7 civilians in Pakistan. Combat drones such as the Predator and Reaper usually carry precision weapons such as Hellfire variations, designed to kill tanks and bust bunkers (Defense News, 31.5.2010). Now a smaller, lighter and more accurate missiles are developed. "You want to hit only the guy you want, not the school bus three cars back", says Steve Felix of the Naval Air Warfare Center (Matthews, 2010). According to Steve Martin, the representative of Lockheed Martin, the aim is to reduce collateral damage: "The bad guys are figuring out how to hide out in homes and near schools. We can't go in and drop large bombs - that just doesn't work any more" (ibid.) One of these new, smaller and lighter missile types is Raytheon's Griffin, currently deployed in Predator drones. "The Griffin's maneuverability and accuracy reduce the risk of "collateral damage"" says an Army representative. "When you can start producing a lower ratio of collateral damage, that's how you win this kind of war", notes Anthony Cordesman from Strategy at the Center for Strategic and and International Studies in Washington, D.C. (Wichner, 2010). No more 'enemy', but virtuous precision to rid the world of the "bad guys".

A glance at the press briefing transcripts from the past years reveals that the Pentagon increasingly refers to the enemy as "the bad guys". The concept of the absolute enemy (see Mouffe, 2005) is particularly obvious in modern military (political) discourse, where 'they' no longer are an adversary, but an absolute evil. The lack of legitimacy of the enemy is demonstrated by titles such as 'bad guys' - they are not recognized as military or as anything the military represents. Instead, they are faceless and in want of status. The enemy is fully visualized only in computer games, where the player is free to shoot.

In July 2010, the Army Experience Center (AEC) in a Philadelphia mall was getting ready to close its door after a successful project. The Center offered visitors information on military careers as well as video games and simulators (some of which are used to train the troops). The youth, wandering the malls, are the perfect target for recruiters. The traditional images of depressing boot camp physical training disappear once the teenagers (13 and older, according to the AEC) get to show with combat simulators what they have been practicing most of their lives. Because 
they know gaming, warfare has to become game-like. Now, the entertainment industry is replacing boot camps. Being good at war is made easy. Being good at war is about pressing a button: In the Army Experience Center, the teenagers can "touch and feel and experience what the army is all about", explains one of the Center's recruiters (thearmyexperience, 2008). High-tech weapons to kill the "bad guys" from a comfortable distance and virtual simulation create combat experience: What ever the problem, the answer lies in technology. This is the Grand Military Narrative.

\section{Background}

The military-industrial complex gave birth to the Revolution in Military Affairs. The future of the military is computers, information networks, and precision-guided munitions (Toffler, 1981, 1993). Technological advances are used to solve the military and strategic challenges of the U.S. (Shimko, 2010: 213). This revolution, or evolution, is depicted by the Grand Military Narrative.

RMA's focus on technology has led to technology-centered strategies and doctrines. Technology offers the option of unmanned war, to "bring knowledge forward" for the people whose observation is limited (Rantapelkonen, 2006:72). "Maximizing output" and "minimizing input" (citing Lyotard, 1984 in Rantapelkonen, 2006:73) match the American ideal of "easy living". Lyotard argues that technology is "good" because it is efficient, not because it is "true", "just" or "beautiful".

According to Rantapelkonen (2006), 'war on terror' is technologically driven. However, the binary image of war contains the idea of not only destroying and devastating, but also avoiding risk, threat and death by liberating, helping and building. Der Derian (2008) calls this "virtuous war". He argues that the military-industrial complex needs binary rhetoric such as 'bombing for peace' and 'killing to live' in order to operate and make profit: technology is in service of virtue. As death and destruction are no longer accepted, technology steps in. By replacing the soldier with a precision (fire-and-forget) weapon, 'targets can be hit' and 'operations conducted' without causing protests on the home front.

The doctrines of Effects Based Operations and Comprehensive Approach are built around the promise of technology. These doctrines are 
characterized by the term precision. Colonel Crowder (U.S. Department of Defense, 2003), much quoted in the upcoming analysis, elaborated on the concept:

Crowder: With the development of the laser-guided bombs, and specifically the laser-guided bombs on aircraft such as the F-111 and the F-117 in Allied -- or, in Desert Storm, we were able to hit two independent targets very precisely with about 10-meter CEP or 10-foot CEP from a single aircraft. When we added additional aircraft, such as the B-2, that capability is now to the point where we can hit multiple targets on a single pass.

[...]

Q: What does CEP stand for?

Crowder: Oh, pardon me. Circular error probable. It is the probability that that weapon will -- that 50 percent of the weapons will land inside that line. So, if what I say basically is -- if I say the CEP of a B-17 in World War II was 3,300 feet, that means there was a high likelihood that 50 percent of the bombs dropped landed with inside 3,300 feet. So not very --

Surely new 21st century missiles are precise. But at the same time, a weapon with a $50 \%$ error margin can still be labeled as a 'precision weapon'. Obviously this is a mere reflection of strategic communication. Precision is now equal to humanity, and legitimizes the Western way of war.

The evolution of warfare demands science is in the service of war. Technology "enables us to do a lot more stuff" and to "more effectively prosecute those operations" (U.S. Department of Defense, 2003). Because of its efficiency and speed, strategies, doctrines and even foreign policy rely on the sole use of technology. The Powell Doctrine aimed to solve problems by overwhelming force in the form of superior weapons technology. Shock and Awe in 2003 worked much the same way.

However, the modern narratives and threat descriptions do not, after all, change much. President Obama no longer uses the term "war on terrorism", but this choice of term did not change the warfare in Afghanistan or Iraq. The US, China, Russia, India, Pakistan, Israel and 
North Korea are still developing nuclear weapons. The new threat descriptions have not removed the old threats. Despite precision munitions, B52 bombers are still in use. The real change first takes place in discourse, but lags behind in realization.

The Grand Military Narrative contains a techno-ideology, which is encoded in language. In this Narrative war has two aspects: the "how" and "why". How wars are conducted is a matter of technology descriptions. Why wars are fought is a matter of value systems. The merge of these two aspects create what is now known as strategic communication.

Not only has the language of the press-briefings, but also soldier-tosoldier communication changed. In the battlefield and combat, propaganda has been replaced by strategic and psychological influence. The global and social media create an increasing influence and new technology solutions create an opportunity to make an impact. Strategic communication exploits all these.

The new generation's war, the Gulf War, was a catalyst to public discussion on the new wave of Information Operations. The Kosovo War and 9/11 sped up the discussion. A whole new narrative was created during the 'War Against Terrorism'.

According to Taylor (2003), the concepts of political, psychological or information warfare are outdated. Instead, we use the concept of 'strategic communication'. Taylor recognizes three types of it. First is "public diplomacy", referring to state and political level. Second is "public affairs", which contains the global media. The third type, Information operations (Info Ops), deals with military capability. Strategic communication has abandoned the Cold War era categories of propaganda: the so called "black" (covert), "white" (overt) and "grey" (unknown) propaganda. Today, the speed of communication is enough to disturb our perception management capability. The 24/7 model takes advantage of our values and understanding of democracy: we say no to censorship and want all information to be available at all times, everywhere.

Strategic communication is a child of the complex world. Instead of rational knowledge, we have information flow. Planning and execution 
are parallel processes; Speed dictates the operational modes, and strategic communication is an attempt to control all this.

\section{Empirical analysis}

\subsection{The Language of Effects Based Operations}

Effects Based Operations (EBO), is a US military concept and doctrine that stands for "operations that are planned, executed, assessed, and adapted based on a holistic understanding of the operational environment in order to influence or change system behavior or capabilities using the integrated application of select instruments of power to achieve directed policy aims". On the day of "Shock and Awe" in 2003, Colonel Gary L. Crowder, chief of strategy, concepts and doctrine, elaborated the concept in layperson's terms in a press briefing dedicated for EBO alone (U.S. Department of Defense, 2003). Before proceeding to explaining any further, the concepts of technology-based approach and doctrine step in. Crowder explains that the new approach was "more than just people, it was the combination of a fortuitous development of different capabilities and technologies [...] that enabled us to do that." The phrases that follow this capture the very essence of the discourse that characterized the American public relations during the beginning of the war:

Instead of a traditional attritional approach in terms of listing a bunch of targets and then go bombing targets, or finding where the enemy is and killing all the enemy, we really determined that what we wanted to do was in fact to achieve some sort of policy objective, and that you could, in fact, craft military operations to better achieve those policy operations in a more efficient and effective manner.

The key words here are "efficient" and "effective". EBO was, according to Crowder, a way to mitigate collateral damage. In order to explain the concepts of "collateral damage" and "unintended damage", Crowder had to discuss risk-taking as part of doctrine.

Crowder explains that even if collateral and unintended damage happen, and "both of these types of damage will take place", they "still went through a methodical process". This precisely is the problem with strategy that relies almost solely on the performance of technology. Technology fails, and when it does, the responsibility of that failure lies 
on technology itself. According to the strategy, both collateral and unintended damage are unavoidable, technology has its fail-ratio, and these are facts that just have to be accepted. In Virilio's (1989: 8-9) terms, Art of War has turned into Science of the Accident.

Technology is complex and when techno-speak enters press briefings such as Crowder's, a new kind of language is created. Zizek (2009) argues that public communication increasingly applies expert and scientific jargon that no longer translates to the 'common speak' of the society. The 'expert speak', despite its abstract nature, still shapes our thinking, especially when it is labeled with adjectives such as 'precision', 'smart' and 'efficiency'. With examples of virtuous warring (liberating) and precise and efficient operating models (avoiding collateral damage), it complies with the modern imperative of clean and safe, effective and lethal, and yet moral and humane war fighting. The kind of war that we will accept.

Although EBO as it was first created and intended is already abandoned by the American Department of Defense, it created a new narrative tradition of virtue and the superiority of technology and binary values. This tradition continues to influence Western military discourses.

In order to pinpoint the Grand Military Narrative of strategic communication, we have to look at the theme and structures of the strategists' language. The United States has an irrefutable position as the military trend-setter and the creator of new military concepts. This makes American strategy papers and press briefings on strategy and doctrine a good resource for analyzing the evolution of strategic communication. The upcoming analysis continues the discussion on strategy, doctrine and Effects Based Operations and their influence on discourse.

The Joint Operating Environment 2010 (JOE10) (United States Joint Forces Command, 2010) provides the framework for our analysis and aims to predict and forecast the future of American warfare. It argues and elaborates on what should be prepared for. The narrative starts from the recognition of the human limitations in the complex world, created by the clash of different ideologies and cultures, and further supplemented by advances in technology and changes in the economy.

The complex world affects, according to the report, the "battle of 
narratives". If winning the battle is important, winning the battle of narratives is "absolutely crucial". The report makes the conclusion that

Dominating the narrative of any operation, whether military or otherwise, pays enormous dividends. [...] In the battle of narratives, the United States must not ignore its ability to bring its considerable soft power to bear in order to reinforce the positive aspects of Joint Force operations. Humanitarian assistance, reconstruction, securing the safety of local populations, military-tomilitary exercises, health care, and disaster relief are just a few examples of the positive measures that we offer.

This statement is interesting, as we have witnessed the emergence of operations 'other than war'. In the narrative of Operation Iraqi Freedom, the military leadership put much focus on the humanitarian aspect of the operation. But, the "battle of narratives" manifested itself not only in word choices such as liberate and humanitarian aid, but also as words such as precision-guided weapons. The emphasis of the use of precision guided munitions can be seen as semantic tactics. Technology is part of the narrative.

JOE10 mentions the words deter and deterrence several times, and finally concludes that deterrence will be the "primary purpose" of the military forces. This explains the threat discourse: the only way to deter is to excel over the rest in skill, capacity and resources. Deterrence will be created by absorbing education and science: "The Services should draw from a breadth and depth of education in a range of relevant disciplines to include history, anthropology, economics, geopolitics, cultural studies, the "hard' sciences, law, and strategic communication", the report states. It also stresses that in future, asymmetric and irregular warfare will be more likely than conventional warfare, and that the U.S. military should be prepared for this:

Irregular wars are more likely, and winning such conflicts will prove just as important to the protection of America's vital interests and the maintenance of global stability.

To summarize the report, we make the following conclusions: in strategy, techno-speak

1. is part of the "battle of narratives" and Strategic Communication

2. is based on threat discourse 
3. serves the function of deterrence on one hand, and legitimation on the other.

The analysis uses these conclusions as the starting point for the linguistic part of the analysis.

\subsection{Methods and data}

The methodology of the analysis builds on the concept of action as a reference to identity and evaluation. It contains three levels of approach: the application of the transitivity system and the process of nominalization.

The transitivity system contains the information on who does what to whom (Butt et al, 2001) and "constries the world of experience into a manageable set off process types" (Halliday, 170). Clause structures typically contain an actor, a process, and a goal or a target (and, of course, much else). The variations in the combination of these elements are significant. In the context of war and conflict, they are a medium for expressing an experience or ideology. For example, Lukin (2005) refers to "doing without doing to" by pointing out that in clause structures such as 'The operation began on the 19th of March', 'Our forces are operating throughout Iraq' or 'A particularly successful operation occurred last night', there is an actor and a process, but no target or goal: the entity impacted by the process is excluded (Lukin, 2005: 6).

The target of the action may also be an abstract of an inanimate entity when referring to 'own' action. The clause structures of enemy action may look very different: the entities impacted are human and far from abstract: women, children and civilians.

We will compare the data to a number of nominal constructions found in the text. The analysis of nominalizations is a methodological tradition in critical discourse analysis. It refers to the grammatical process of turning a verb into a noun or a nominal construction: quit - quitter, fail - failure, etc. Nominalization brings grammatical metaphors into discourse. As Martin (2011: 803) writes,

[N]ominalization (and derivation in general) is a resource for extending the lexical resources of a language. Grammatical metaphor, by contrast, is a resource for scrambling, within limits, 
the realization relationship between semantics and grammar and so indefinitely extending a language's meaning potential. This is much more than a vocabulary-building exercise. It allows writers, and people who learn to speak writing, to mean more than one thing at once.

In the framework of this article, nominalizations are thus an extension of the very action descriptions first discussed.

The data of the analysis comes from a press briefing transcript that aired on the same day when the coalition forces started the Operation Iraqi Freedom by bombing Baghdad. In this briefing, Colonel Gary Crowder (the division chief at Air Combat Command and the plans director for Strategy, Concepts and Doctrine) introduces the concept of Effects Based Operations (EBO) to the press and the public. It can be found online in the US Department of Defense transcript archive with the title Effects Based Operations Briefing.

\subsection{Results}

The analysis consists of two categories of action descriptions: of those,

\begin{tabular}{|c|c|c|c|c|}
\hline & ACTOR & $\begin{array}{l}\text { PROCESS } \\
\text { (material) }\end{array}$ & $\begin{array}{l}\text { BENEF } \\
\text { ICIARY }\end{array}$ & \\
\hline 1 & $\begin{array}{l}\text { these } \\
\text { analytical } \\
\text { tools }\end{array}$ & enable & us $[\ldots]$ & to find alternative methodologies \\
\hline 2 & {$[\mathrm{PGM}][\ldots]$} & give & us & $\begin{array}{l}\text { the ability for a large number of } \\
\text { other aircraft besides just stealth } \\
\text { aircraft to hit multiple weapons per } \\
\text { targets. }\end{array}$ \\
\hline 3 & $\begin{array}{l}\text { its stealth } \\
\text { qualities }\end{array}$ & enable & us & to do a large number of things \\
\hline 4 & [the stealth] & enables & us & to do a lot more stuff \\
\hline 5 & the stealth & does give & us & $\begin{array}{l}\text { some capabilities in addition to the } \\
\text { precision }\end{array}$ \\
\hline
\end{tabular}

Table 1: Technology as a Doer 
where the 'doer' is technology, and of those, where the 'doer' is 'us' (the US, Coalition Forces, etc). When looking at the clauses where technology is the Actor, the main observations are that in these descriptions the typical process is a description of 'enabling', and the object of action (Goal or Range, often in a projected clause) is abstract or ambiguous as seen in the table above.

In action descriptions where the Actor is human or animate, there are two main types. The first type are the descriptions of dynamic military action and capability:

\begin{tabular}{|l|l|l|l|l|}
\hline & $\begin{array}{l}\text { ACTOR/ } \\
\text { CARRIER }\end{array}$ & $\begin{array}{l}\text { PROCESS } \\
\text { (material } \\
\text { relational) }\end{array}$ & $\begin{array}{l}\text { GOAL/RANGE/ } \\
\text { POSSESSED }\end{array}$ & \\
\hline 6 & we & $\begin{array}{l}\text { were able to } \\
\text { take down }\end{array}$ & $\begin{array}{l}\text { the air defense } \\
\text { system }\end{array}$ & \\
\hline 7 & we & $\begin{array}{l}\text { were able to } \\
\text { neutralize }\end{array}$ & those towers & \\
\hline 8 & we & can hit & multiple targets & \\
\hline 9 & we & have & $\begin{array}{l}\text { much more dual- } \\
\text { use capability }\end{array}$ & $\begin{array}{l}\text { in each of the Air Force's, } \\
\text { Navy's and Marines' fighter } \\
\text { aircraft as well as our } \\
\text { bomber aircraft }\end{array}$ \\
\hline 10 & we & have & $\begin{array}{l}\text { an improved } \\
\text { ability }\end{array}$ & $\begin{array}{l}\text { go after adversary's } \\
\text { systems }\end{array}$ \\
\hline
\end{tabular}

Table 2: Human as a Doer

The action descriptions refer to the use of weapons and technology. In descriptions of military action, the process is typically material (physical) and the object of the action is inanimate and often abstract. The data also contains a number of possessive attributive action descriptions (having something), where the entity possessed is typically capability or ability, both abstract. The evaluation of the first ten sample clauses is positive. The Process (often combined with the Goal/Range) signal social esteem in the form of capacity; Technology and Self are described as competent, expert and powerful. The objects of action are inanimate, which signals 
Social Sanction: the one acting is good, moral and ethical by attacking non-human targets.

The second type consists of action descriptions that are somewhere between material and mental processes:

\begin{tabular}{|c|c|c|c|}
\hline$\#$ & SENSER & PROCESS (mental) & PHENOMENON \\
\hline 11 & I & would prioritize $[\ldots]$ & those targets \\
\hline 12 & we & look & $\begin{array}{l}\text { at the desired effects we want to } \\
\text { create on the battle space, }\end{array}$ \\
\hline 13 & we & evaluate & $\begin{array}{l}\text { the target sets that we need to do, } \\
\text { that -- those effects that we need to } \\
\text { create on the battle space }\end{array}$ \\
\hline 14 & we & bring & those together into a integrated plan \\
\hline 15 & $\begin{array}{l}\text { we } \\
\text { literally }\end{array}$ & come up & with a high heaven objective \\
\hline
\end{tabular}

Table 3: Human as a Doer

These descriptions highlight the analytical part of waging war: the planning and the creating of strategy. In this context we will analyze them as mental processes, because they are strongly contrastive to the material processes of attacking and neutralizing, and their purpose is to emphasize the role of the scientific and creative planning process in warfare. The evaluation in the above clauses is, just like in the first ten, positive. Capacity is signaled with descriptions of observation, consideration and learnedness. These Process types can further be characterized as perceptive and cognitive (Halliday, 2004: 210).

To put it briefly, the source text emphasizes Capacity that is realized by descriptions of having both inner (ability, cognitive skills) and outer (material, technological) resources. Of all action, the emphasis is on inner experience: weapons are of course used, but after a planning process that 
is described as highly scientific.

In addition to action descriptions, the briefing contained a number of nominal constructions that are worth notice:

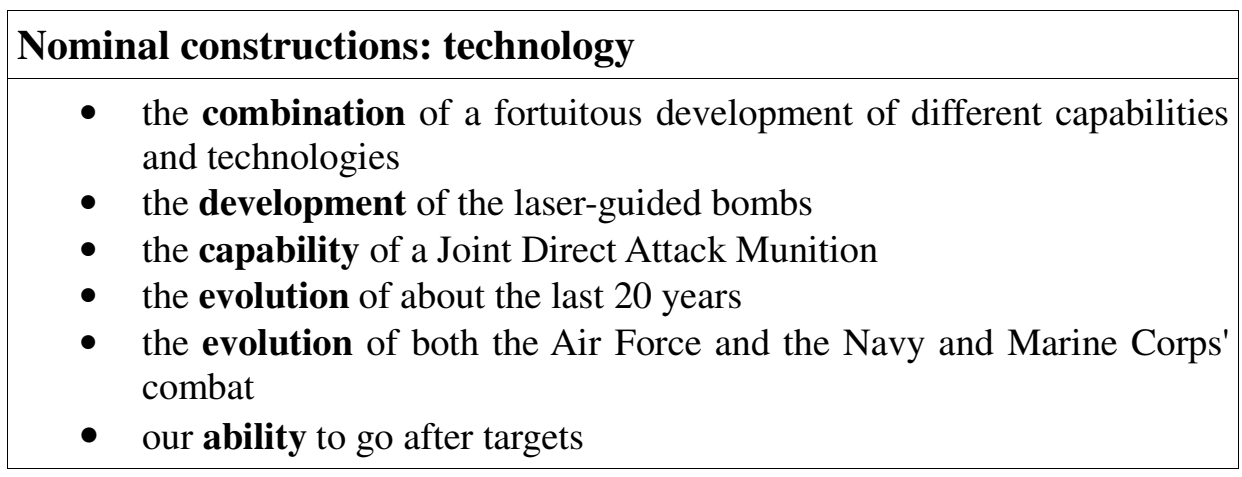

\section{Table 4: Nominalizations}

The above nominalizations capture the semantic content of the action descriptions: development, capability, evolution, ability. The order of these nominalizations create a narrative of evolving and developing capability that finally is utilized as an ability. This narrative creates a concept of advancement and technological omnipotence.

\section{Discussion}

There are two major players in the Grand Narrative of War: technology is the enabler, and 'we' are the able. The ability technology creates is to wage war effectively, precisely and securely and so save lives by avoiding casualties and collateral damage. Technology is the prerequisite for humanity in warfare. In this narrative, war has evolved into "Effects Based Operations" on one hand, and into humanitarian operations on the other. The result is war's new image, which is slowly drifting further and further away from the killing, and closer and closer to implementing humanity. This is the source of the binary rhetoric of 'bombing for peace' and 'destroying the village to save it'.

The frequently occurring words capacity and capability are abstract and subordinate terms that may mean anything from having financial or human resources to operate to meaning the quality of weapons systems, 
planning, or the mass of the actual weapons. These are everyday terms in strategy and operations discussed in public and allow the speaker to carry out the tactic of neutrality through vagueness.

The technology descriptions in American war-speak execute the function of deterrence. As Joint Operational Environment 2010 (United States Joint Forces Command, 2010) concludes, the task of deterrence will be increasingly important. This, although, evokes the question whether the asymmetric and irregular enemy the report described can be deterred and if so, whether technology as a deterrence will work. Insurgents use inexpensive and asymmetric forms of combat, to which the U.S. responds with expensive counter measures. According to 2008 National Defense Strategy, deterrence must include both military and non-military tools, and that "changes in capabilities, especially new technologies" help to create a credible deterrence. Metz (2007: 65) elaborates on the logic of fighting insurgency with technology:

Counterinsurgency experts long have argued that technology is unimportant in this type of conflict. While it is certainly correct that technology designed to find and destroy a conventional enemy military force had limited application, other types such as nonlethal weapons and robotics do hold promise for difficult tasks such as securing populated areas, preventing infiltration, and avoiding civilian casualties.

While the counterinsurgency (COIN) strategy emphasizes the integration of military and non-military means, the military still turns to technology for answers. EBO, once justified with the promise of new technologies, has been abandoned and replaced with the 'Comprehensive Approach' (CA). These new strategies are justified as they promise 'even less' collateral damage and 'even better' precision - enabled by technology. The name of the applied strategies change, but the discourses (and the weapons used) remain the same. The deterrence the West imposes means smaller and smaller missiles (yet more lethal than ever), satellites and stealth drones (that both observe us and guide missiles) and cyberspace. Virilio (2009) calls this "aesthetics of disappearance". The collective Western outlook no longer tolerates alternatives that would make war visible. At the same time, we fear the unseen.

The Joint Operating Environment 2010 (ibid.) also remarks that 
individual soldiers are increasingly "global communication producers". According to the report, in the "battle of narratives" the role of the "strategic corporal whose acts might have strategic consequences if widely reported" is big. By press-briefing the media and embedding journalists in 'liberation operations', the military leadership is creating strategic communication that is convincing enough to appeal not only to the public, but also to the soldier that has to be supervised and controlled by the system and as part of the system - not as an individual. In the words of the COIN Field Manual: "Information operations (IO) must be aggressively employed" to "obtain local, regional, and international support for COIN operations" and "discredit insurgent propaganda and provide a more compelling alternative to the insurgent ideology and narrative".

\section{Conclusion}

The Revolution in Military Affairs presents the new identity of war as a system of technologies, an ideology which manifests itself in military discourse. In addition, system thinking, such as EBO, has created the demand for both internal and external control in the Western military force. This combination of strategically significant military contractors, techno-faith and the need to dominate and control have led to strategic communication, which contains the Grand Military Narrative. According to this Grand Narrative, technology executes, with precision, reliability and from a distance, the duties determined by analytical, rational and morally virtuous humans. The public role of the military is to 'do good'. In this narrative, war is removed from the battle fields into the virtual.

The binary roles of the military result in binary rhetoric, and this is very visible in the analysis introduced in this article. Whereas the adversary, the insurgents, conduct hands-on warfare based on the assumption that the insurgent will die in the process, the West distances itself from the discomfort both physically (drones and missiles) and mentally (distance and simulation) and tolerate no losses. 'We' cling onto everything we have, whereas 'they' have little to lose. 'We' fight the enemy with the exact opposite way than they fight 'us': the US is portrayed as evolved and scientific, while the majority of the militaries in the rest of the world employ very different methods of warfare. This makes the discourse on the threats of asymmetric enemies interesting. Is it not the RMA that distanced 'us' from the enemy and created asymmetry, the Frankenstein 
we are now terrified of?

The Grand Military Narrative is full of paradoxes. Rhetoric, strategy and reality do not meet. The result is that we are deterring an asymmetric enemy (that cannot be deterred) with weapons (that cannot be seen) and pay more than we can afford to in order to do so (while the enemy pays close to nothing). The paradox here is that in an arms race against asymmetric enemies, the winner is not the one who has the highest technology, but the one who tolerates the biggest losses.

\section{References}

Butt, D. et al. (2001) Using functional grammar: An explorer's guide. 2nd edition. Sydney: Macquarie University.

Der Derian, J. (2009) Virtuous War, New York: Routledge.

Halliday, M.A.C. (2004) An Introduction to Functional Grammar. Revised by Matthiessen, C.M.I.M, London: Arnold.

Lukin, A. (2005) 'Information warfare: The grammar of talking war', Social Alternatives Vol. 24 No. 1,First Quarter, pp. 5-10.

Martin, J.R. (2011) Incongruent and proud: de-vilifying 'nominalization'. Discourse \& Society Vol 19 No. 6, pp. 801-810.

Martin, J.R. and White, P.R.R. (2005) The language of evaluation: Appraisal in English, New York: Palgrave Macmillan.

Matthews, W. (2010) 'Smaller, Lighter, Cheaper: New Missiles Are 'Absolutely Ideal' for Irregular Warfare', Defense News, 31 May, [Online], Available: http://www.defensenews.com/story.php?i=4649372 [19 Oct 2010]

Metz, S. (2007) Learning from Iraq: Counterinsurgency in American strategy, [Online],Available:

http://www.strategicstudiesinstitute.army.mil/pubs/download.cfm?q=752 [19 Oct 2010].

Mouffe, C. (2005) On the political. London: Routledge.

Rantapelkonen, J. (2006) The Narrative Leadership of War: Presidential Phrases in the 'War on Terror'and their Relation to Information Technology. Doctoral Dissertation. Publication Series 1, Research n:o 34, Helsinki: National Defence University.

Shimko, K. L. (2010) The Iraq Wars and America's Military Revolution, New York: Cambridge University Press.

Taylor, P. (2003) Munitions of the Mind: A History of Propaganda from the Ancient World to the Present Day, 3rd edition, Manchester: Manchester University Press.

Thearmyexperience (2008) Inside the Army Experience Center, [video online] Available:http://www.youtube.com/watch?v=-1ZKV9bP_0Q [19 Oct 2010]

Toffler, A. (1981) The Third Wave, New York: Bantam Books.

Toffler, A . \& Toffler, H. (1993) War and Anti-War: Survival at the Dawn of the 21st Century, Boston:Little, Brown \& Co.

United States Joint Forces Command. (2010) The Joint Operating Environment 
http://www.jfcom.mil/newslink/storyarchive/2010/JOE_2010_o.pdf [19 Oct 2010].

U.S. Department of Defense (2008) 2008 National Defense Strategy, [Online], Available: http://www.defense.gov/news/2008\%20national\%20defense\%20strategy.pdf [19 Oct 2010]

U.S. Department of Defense (2003) Effects Based Operations Briefing.Transcript, 19 March, [Online], Available: http://www.defense.gov/Transcripts/Transcript.aspxTranscriptID=2067 [19 Oct 2010]

Wichner, D. (2010) 'Raytheon's new Griffin fit for drone', Arizona Daily star, 22 Aug, [Online] Available: http://azstarnet.com/business/local/article_ff437ef6-c69d56c6-aeff-e74d0d5902b9.html [19 Oct 2010]

Virilio, P. (2009) The Aesthetics of Disappearance, Translated by Philip Beitchman, Los Angeles: Semiotext(e).

Virilio, P. (1989) War and Cinema. The Logistics of Perception, Translated by Patrick Camiller, London: Verso.

Zizek, S. (2009) Pehmeä vallankumous. Translated by Janne Porttikivi, Helsinki: Gaudeamus. 